\title{
Shifts in the regeneration niche of an endangered tree (Acer opalus ssp. granatense) during ontogeny: Using an ecological concept for application
}

\author{
José L Quero ${ }^{\mathrm{a}, *}$, Lorena Gómez-Aparicio ${ }^{\mathrm{a}, 1}$, Regino Zamora ${ }^{\mathrm{a}}$, Fernando T. Maestre ${ }^{\mathrm{b}}$ \\ ${ }^{a}$ Grupo Ecología Terrestre, Departamento de Ecología, Facultad de Ciencias, Universidad de Granada, Avda. Fuentenueva s/n, \\ E-18071 Granada, Spain \\ b'Área de Biodiversidad y Conservación, Escuela Superior de Ciencias Experimentales y Tecnología, \\ Universidad Rey Juan Carlos, cl Tulipán s/n, E-28933 Móstoles, Spain
}

\section{Summary}

Most of our knowledge regarding ontogenetic niche shifts in plants has been derived from studies involving only two or unconnected life stages. Approaches covering a broader range of different life stages are still needed to fully understand the implications of ontogenetic niche shifts for plant regeneration dynamics. We investigated ontogenetic shifts in the endangered Mediterranean tree species Acer opalus ssp. granatense (A. opalus) comparing the environmental characteristics of individuals of different ages with those of a random sample of available microsites. In addition, since herbivory could be a limiting factor, herbivory damage was quantified. Differences in environmental characteristics between locations of individual plants and randomly selected points became larger with plant age, suggesting that the regeneration niche of $A$. opalus shifts during ontogeny, undergoing a contraction. The presence of shrubs and adult trees, the depth of the litter layer, and herbivory were the main factors influencing these changes. A. opalus can germinate in all available microhabitats its seeds can reach, but saplings establish and grow only in a subset of microhabitats, which represent a change in tolerance to extrinsic factors. Old saplings establish under the canopy of shrubs, far away from tree cover that could block light required in the oldest stage. Therefore, temporal changes in the nature and strength of plant-plant interactions are also occurring. The ecological concept of niche shifts reveals the microsites with higher probabilities of long-term sapling survival of A. opalus: shrub cover involves an array of environmental changes crucial for the successful establishment of $A$. opalus saplings under stressful Mediterranean conditions, from microhabitat amelioration to herbivory protection.

\section{Zusammenfassung}

Der größte Teil unseres Wissens über ontogenetischen Nischenverschiebung bei Pflanzen wurde in Untersuchungen gewonnen, die nur zwei oder nicht verbundene Lebensabschnitte berücksichtigen. Es werden immer noch Ansätze benötigt, die eine größere Bandbreite von verschiedenen Lebensstadien abdecken, um Implikationen von ontogenetischer Nischenverschiebung für die Dynamik der Pflanzenregeneration zu verstehen. Wir untersuchten ontogenetische Veränderungen bei der gefährdeten mediterranen Baumart Acer opalus spp. granatense (A. opalus) 
indem wir die Umweltcharakteristiken von Individuen verschiedenen Alters mit denen von einer zufälligen Auswahl von verfügbaren Mikrohabitaten verglichen. Zusätzlich wurde die Beschädigung durch Herbivorie quantifiziert, da Herbivorie ein limitierender Faktor sein könnte. Die Unterschiede in den Umweltcharakteristiken zwischen den Standorten individueller Pflanzen und zufällig ausgewählten Standorten wurden mit zunehmenden Pflanzenalter größer, und lassen vermuten, dass sich die Regenerationsnische von A. opalus verändert indem sie sich verkleinert. Das Vorhandensein von Büschen und ausgewachsenen Bäumen, die Tiefe der Streuauflage und Herbivorie waren die Hauptfaktoren, die diese Veränderungen beeinflussten. A. opalus kann in allen verfügbaren Mikrohabitaten keimen, die von den Samen erreicht werden, aber die Schösslinge etablieren sich und wachsen nur in einem Teil der Mikrohabitate, was eine Änderung der Toleranz gegenüber äußeren Faktoren darstellt. Ältere Schösslinge etablieren sich unter der Deckung von Büschen, weit weg von einem Kronendach, welches das Licht blockieren könnte, das im ältesten Stadium benötigt wird. Deshalb finden auch zeitliche Veränderungen in der Art und Stärke von PflanzenPflanzen-Interaktionen statt. Das ökologische Konzept der Nischenverschiebung lässt die Mikrohabitate erkennen, die eine höhere Wahrscheinlichkeit für ein langfristiges Überleben von A. opalus Schösslingen aufweisen: Buschdeckung beinhaltet eine Reihe von Umweltveränderungen, die für eine erfolgreiche Etablierung von A. opalus Schösslingen unter den schwierigen mediterranen Bedingungen entscheidend sind, wie die Verbesserung des Mikrohabitats und der Schutz vor Herbivorie.

Keywords: Acer opalus spp. granatense; Mediterranean mountain; Ontogenetic shift; Regeneration niche; Tree regeneration

\section{Introduction}

To a large extent, the abundance and distribution of plant species are determined during early regeneration stages, when seedlings and saplings are most vulnerable to their immediate environment (Kitajima \& Fenner, 2000; Zoladeski \& Maycock, 1990). Thus, it is not surprising that the so-called "regeneration niche" (characteristics of the environment at the time of establishment; Grubb, 1977) is crucial for understanding the composition, structure, and dynamics of plant communities in a variety of environments (Silvertown, 2004). Recent studies suggest that the regeneration niche changes over the life cycle of individuals (Chase \& Leibold, 2003; Miriti, 2006). These changes, known as ontogenetic niche shifts (Parrish \& Bazzaz, 1985), have been widely explored in animal ecology (e.g. Amundsen et al., 2003; Post, 2003). However, knowledge regarding ontogenetic niche shifts in plants is much more limited. The studies available have analysed only two life stages, often unconnected, such as seeds and seedlings (Schupp \& Fuentes, 1995), seedlings and mature trees (CavenderBares \& Bazzaz, 2000), or juveniles of different ages (Espelta, Riba, \& Retana, 1995). Approaches involving a broader range of different life stages are still needed to understand fully whether ontogenetic niche shifts drive the spatial distribution and successional dynamics of plant communities (Grubb, 1977).

Plants do not actively seek ideal habitats, but they exhibit distinct differences in tolerances to extrinsic factors at different developmental stages (Franco \& Nobel, 1989; Miriti, 2006; Parrish \& Bazzaz, 1985), causing changes in niche dimension. A niche expansion occurs when species requirements are stricter in earlier stages, whereas a niche contraction would indicate that requirements are stricter in later stages of development. Parrish and Bazzaz (1985) considered niche expansion the most common situation for plants, since species requirements were usually narrow at the germination stage and broader at the seedling and adult stages. Contrary to this, niche contraction could limit the establishment of a plant by restricting it to a subset of environmental characteristics within the potential scenarios that can be occupied by the species.

The demographic responses of different stages to abiotic and biotic conditions will be expressed in different ways (e.g. differential mortality rates of seedlings, and differential growth or reproductive allocation of larger plants, Miriti, 2006; Parrish \& Bazzaz, 1985). Such ontogenetic constraints are often critical in understanding the whole dynamic of a plant population in which a particular stage needs specific conditions not shared by other life stages. A paradigm to the significance of ontogenetic changes is that shifting conditions alternatively favour positive or negative interactions among plants different in size (Callaway, 1995; Holmgren, Scheffer, \& Huston, 1997; Holzapfel \& Mahall, 1999). Whatever the case, proper knowledge of ontogenetic niche changes is essential from both a basic and applied standpoint in order to increase our understanding of the processes underlying niche shifts as well as to establish appropriate management and restoration plans that consider the microsites where the species has higher probabilities of long-term survival.

The Mediterranean tree Acer opalus ssp. granatense (Boiss.) Font Quer and Rothm (hereafter A. opalus) is an ideal species to evaluate ontogenetic niche shifts because: (i) the wind dispersal of its seeds facilitates the 
spatial distribution and emergence of $A$. opalus seeds in a wide range of microhabitats (Gómez-Aparicio, Gómez, \& Zamora, 2005); (ii) its architectural attributes, with growth scars on the main stem, facilitate accurate age determinations of saplings (see Boerner \& Brinkman, 1996 and Taylor \& Aarssen, 1989 on Acer saccharum Marsh). Furthermore, Mediterranean forests constitute an excellent model to analyse ontogenetic niche shifts, since juveniles of woody species have a delayed growing period due to climatic stress (Castro, Zamora, \& Hódar, 2006; Castro, Zamora, Hódar, Gómez, \& Gómez-Aparicio, 2004; Zamora, Gómez, Hódar, Castro, \& García, 2001), and therefore the transition from seedling to established larger sapling is delayed in comparison to tropical or temperate forests.

Here, we report results from a study designed to evaluate whether $A$. opalus undergoes ontogenetic niche shifts, since the transition from seedlings to old saplings is a strong candidate to reveal niche shifts. Both the seed-dispersion and seedling-emergence demographic stages of $A$. opalus are strongly connected, because seedling spatial distribution is a mirror of seed-rain spatial distribution (Gómez-Aparicio, Gómez, et al., 2005). Furthermore, mortality of A. opalus saplings is insignificant (Gómez-Aparicio, Zamora, Castro, \& Hódar, in press), and hence, the distribution and abundance of old saplings can be considered very similar to that of adult trees. For these reasons, our ontogenetic study of $A$. opalus, from seedlings to established old saplings, offers an adequate picture of the entire life cycle in this species (dispersal to adult). Specifically, we seek to answer the following questions: (i) Do ontogenetic niche shifts occur in A. opalus? (ii) If so, do they reflect niche expansion or contraction among stages (sensu Eriksson, 2002)? (iii) What variables drive such shifts? For the answers, we followed the "plant's eye-view" approach (Turkington \& Harper, 1979), conducting a multivariate characterization of the environment in the immediate vicinity of individuals of different ages.

\section{Materials and methods}

\section{Natural history and study site}

A. opalus is an endemic Iberian-Mauritanian species with a patchy geographical distribution within the Iberian Peninsula (Gómez-Aparicio, Zamora, \& Gómez, 2005). Its populations appear usually in areas where Mediterranean summer drought is ameliorated, such as in north-facing slopes, in shady ravines or in the surroundings of riverbanks (Costa, Morla, \& Sainz, 1998). It has been catalogued as "vulnerable" by the IUCN (2000) and is included in the recent Red List of Threatened Vascular Plants of Andalusia (Blanca,
Cabezudo, \& Hernández-Bermejo, 2000). Seed dispersal occurs from September to December and seedlings emerge during the next spring (April-June).

The study was conducted during spring 2004 in the Sierra Nevada National Park (Barranco del Espinar, $1700-1950$ m. a. s. $1 . ; 37^{\circ} 06^{\prime} \mathrm{N}, 3^{\circ} 21^{\prime} \mathrm{W}$; Granada, SE Spain). The vegetation of this native mixed mountain forest is dominated by trees (Pinus sylvestris L. var. nevadensis Christ., A. opalus ssp. granatense and Taxus baccata L.), with a dense shrub understorey dominated by fleshy-fruited shrubs (Juniperus communis L., J. sabina L. and Berberis hispanica Boiss. and Reut.) and non-fleshy-fruited (Ononis aragonensis Asso., Genista versicolor Boiss. and Erinacea anthyllis Link.) shrubs (García, Zamora, Hódar, Gómez, \& Castro, 2000). The climate is typical of Mediterranean mountains: mean annual rainfall of $879 \mathrm{~mm}$ (average 1990-2003) with hot, dry summers and cold, snowy winters. The bedrock is calcareous and soils are regosols and cambisols (Delgado et al., 1989).

\section{Field sampling}

For this study, A. opalus individuals were grouped into three age classes: "seedlings", that emerged in the spring of the study, still with cotyledons; "young saplings" (from 2 to 5 years old), and "old saplings" (from 6 to 10 years old). Age was determined by counting growth scars on the main stem (GómezAparicio, Zamora, et al., 2005). Average height (mean$\mathrm{s} \pm \mathrm{SE}$ ) was $3.5 \pm 0.15,6.5 \pm 0.35$, and $32.9 \pm 18.4 \mathrm{~cm}$ for seedlings, young saplings, and old saplings, respectively. A. opalus individuals were sampled using twelve $25-\mathrm{m}$ transects randomly distributed throughout the study site. In each transect, random points were generated (in order to compare them to those points with A. opalus individuals) by using haphazard number lists of orientations $\left(0-359^{\circ}\right)$ and distances $(0-7 \mathrm{~m})$ every $5 \mathrm{~m}$ (at metres $0,5,10,15,20$ of the transect for seedlings, metres $1,6,11,16,21$ for young saplings, and metres 2 , $7,12,17,22$ for old saplings). Plants were selected for analysis by locating the nearest $A$. opalus seedling or sapling to each of these random points. Sampling did not have spatial dependence since distances between individuals and random points did not differ among age classes (ANOVA, $F_{2,177}=1.65, P=0.177$ ). A total of 60 random points and $60 \mathrm{~A}$. opalus individuals per age class were selected for measurements, resulting in 360 points measured.

At each sampled point (with and without plants), the following environmental variables were measured in a circular plot $0.30 \mathrm{~m}$ in diameter, for seedlings and young saplings, or $0.50 \mathrm{~m}$ for old saplings, according to class size: (1) average soil compaction, (2) depth of the maximum soil-compaction value, (3) light availability, 
(4) distance to the nearest $A$. opalus adult tree, (5) depth of the litter layer, (6) number of woody species present, (7) cover of herbaceous species, (8) moss cover, (9) stone cover, (10) tree cover and (11) shrub cover. Soil compaction was measured using a Penetrologger penetrometer (Eijkelcamp, Giesbeek, The Netherlands). This device provides a profile describing the variation of soil compaction with depth at each point sampled. From these profiles, two variables relevant for rooting capacity, and thus for seedling establishment (GómezAparicio, Valladares, Zamora, \& Quero, 2005), were determined: the average compaction over the profile (MPa), and the depth of maximum compaction $(\mathrm{cm})$. Light availability (global site factor, hereafter, GSF) was quantified with hemispherical photography. Photographs were taken at each sample point at ground level using a horizontally levelled digital camera (CoolPix 5000, Nikon, Tokyo, Japan) and aimed at the zenith, using a fish-eye lens of $180^{\circ}$ field of view (FCE8, Nikon). To ensure homogeneous illumination of the canopy and a correct contrast between canopy and sky, all photographs were taken before sunrise, after sunset, or on cloudy days. The images were analysed using Hemiview canopy analysis software version 2.1 (1999, delta-T Devices Ltd, Cambridge, UK). The software estimates the GSF, defined as the proportion of diffuse and direct radiation for clear-sky conditions at our study site (Rich, 1990). GSF is a continuous variable ranging from 1 (open sky) to 0 (complete obstruction). The distance to the nearest adult $A$. opalus tree was measured with a laser distance-meter (model Disto lite, Leica Geosystem, Heerbrugg, Switzerland). The depth of the litter layer was measured by inserting a metal ruler down to the soil surface. The different percentages of cover were visually estimated by dividing the circular plot into four equal sections to ensure more accurate measurements. Since A. opalus can undergo increasing risk of herbivory with age (Gómez-Aparicio, Zamora, et al., 2005), yearly herbivore damage was recorded in each individual and age class as the percentage of consumed twigs. Because herbivory damage was marginal in seedlings and young saplings ( 2 individuals out of every 60 in each age class), we explored differences in herbivory among microsites only in old saplings.

\section{Data analysis}

To evaluate whether the environmental variables measured differed between age classes (seedlings, young saplings and old saplings) and point type (with and without $A$. opalus individuals), the semi-parametric multivariate analysis of variance approach of Anderson (2001) was used (hereafter PERMANOVA). This approach allows the testing of the simultaneous responses of a multivariate dataset to one or more factors in an ANOVA experimental design on the basis of any distance measure using permutation methods (see Anderson, 2001 and McArdle \& Anderson, 2001 for details). In addition to PERMANOVA analyses, we conducted a canonical analysis of principal coordinates (PCO) to identify the particular environmental variables responsible for the multivariate patterns observed (see Anderson \& Willis, 2003 for a detailed account of the method). In brief, this method performs a principalcoordinate analysis of a multivariate matrix using a dissimilarity measure of choice to provide a series of $m$ orthonormal axes. A canonical discriminate analysis is then conducted on the first $m$ axes. The canonical axes resulting from this ordination are derived from linear combinations of variables that maximize the differences between the different experimental groups (in our case the 6 groups resulting from each combination of point type and age class). The first two axes were correlated with the environmental variables measured using the Spearman correlation coefficient; the variables with the highest absolute correlations will likely determine the differences between points with and without A. opalus individuals, as well as between microsites occupied by individuals of different age classes. Bonferroni correction was applied to be conservative in detection of significance from multiple pair-wise correlation analyses. PERMANOVA and PCO analyses were performed using the programs PERMANOVA 1.6 (Anderson, 2005) and CAP (Anderson, 2004), respectively (both can be freely downloaded from http:// www.stat.auckland.ac.nz/ mja/Programs.htm). For these analyses, we used Bray-Curtis distance (appropriate for the datasets containing a miscellaneous mixture of variables and numerous zeros; Quinn \& Keough, 2002) and 10000 permutations (permutation of raw data; Anderson \& Ter Braak, 2003). Correlation analyses were conducted with the programme SPSS 10.0 for Windows (SPSS Inc., Chicago, IL, USA).

To evaluate whether herbivory damage in old saplings differed among microsites, a one-way ANOVA was used. Microsites were grouped into four categories according to predominant cover: tree, palatable shrub (O. aragonensis), non-palatable shrub (Juniperus spp. and $B$. hispanica) and open. Palatability criteria were based on Baraza, Zamora, and Hódar (2006).

\section{Results}

The environmental characteristics of the locations occupied by seedlings and saplings differed from those of the randomly located points (PERMANOVA, $F=3.30, P=0.0043$; Table 1). Moreover, there were significant differences among age classes (PERMANOVA, $F=4.49, \quad P=0.001)$. A marginally significant point type $\times$ age interaction was also found (PERMANOVA, 
Table 1. Values of the environmental variables measured across age classes (seedlings $=1$ year old; young saplings $=$ from 2 to 5 years old; and old saplings $=$ from 6 to 10 years old) and point type (with and without $A$. opalus individuals) levels.

\begin{tabular}{|c|c|c|c|c|c|c|}
\hline & \multicolumn{2}{|l|}{ Seedlings } & \multicolumn{2}{|c|}{ Young saplings } & \multicolumn{2}{|l|}{ Old saplings } \\
\hline & $\begin{array}{l}\text { With } \\
\text { plants }\end{array}$ & $\begin{array}{l}\text { Without } \\
\text { plants }\end{array}$ & $\begin{array}{l}\text { With } \\
\text { plants }\end{array}$ & $\begin{array}{l}\text { Without } \\
\text { plants }\end{array}$ & $\begin{array}{l}\text { With } \\
\text { plants }\end{array}$ & $\begin{array}{l}\text { Without } \\
\text { plants }\end{array}$ \\
\hline Average compaction (MPa) & $141.8 \pm 8.9$ & $122.4 \pm 8.9$ & $141.9 \pm 10.7$ & $141.8 \pm 9.3$ & $149.4 \pm 8.8$ & $132.4 \pm 9.7$ \\
\hline Depth of maximum compaction $(\mathrm{cm})$ & $20.6 \pm 1.3$ & $23.3 \pm 1.4$ & $25.1 \pm 1.3$ & $22.7 \pm 1.3$ & $24.2 \pm 1.4$ & $23.4 \pm 1.6$ \\
\hline Global site factor & $0.289 \pm 0.025$ & $0.340 \pm 0.030$ & $0.253 \pm 0.022$ & $0.325 \pm 0.029$ & $0.326 \pm 0.027$ & $0.345 \pm 0.029$ \\
\hline Herbaceous cover $(\%)$ & $10.6 \pm 2.4$ & $10.8 \pm 2.8$ & $12.5 \pm 2.8$ & $12.4 \pm 2.7$ & $10.4 \pm 2.5$ & $8.8 \pm 2.7$ \\
\hline Litter depth (mm) & $16.5 \pm 1.4$ & $17.2 \pm 1.6$ & $23.1 \pm 1.5$ & $16.9 \pm 1.8$ & $27.4 \pm 1.9$ & $18.8 \pm 2.3$ \\
\hline Moss cover $(\%)$ & $3.3 \pm 1.5$ & $5.2 \pm 1.8$ & $10.3 \pm 3.0$ & $4.9 \pm 2.6$ & $10.8 \pm 3.0$ & $5.4 \pm 2.8$ \\
\hline Distance to nearest adult $A$. opalus $(\mathrm{m})$ & $8.5 \pm 0.8$ & $12.3 \pm 1.2$ & $10.9 \pm 0.8$ & $10.9 \pm 0.8$ & $11.3 \pm 1.0$ & $10.3 \pm 0.8$ \\
\hline Shrub cover $(\%)$ & $31.7 \pm 4.9$ & $40.6 \pm 5.7$ & $62.7 \pm 5.4$ & $46.0 \pm 5.9$ & $61.8 \pm 4.8$ & $43.1 \pm 4.9$ \\
\hline Stone cover $(\%)$ & $14.2 \pm 2.9$ & $11.7 \pm 2.3$ & $12.2 \pm 2.4$ & $13.4 \pm 2.8$ & $16.3 \mathrm{v} 2.9$ & $20.6 \pm 3.5$ \\
\hline Tree cover $(\%)$ & $47.2 \pm 6.4$ & $51.5 \pm 6.4$ & $35.3 \pm 6.2$ & $36.5 \pm 6.2$ & $25.3 \pm 5.5$ & $38.2 \pm 6.2$ \\
\hline Number of individual of woody & $1.1 \pm 0.1$ & $1.1 \pm 0.2$ & $1.1 \pm 0.1$ & $0.9 \pm 0.2$ & $2.2 \pm 0.2$ & $1.6 \pm 0.2$ \\
\hline
\end{tabular}

Significant differences $(P<0.05)$ between "with plants"-“without plants" pairs within age classes are shown in bold type (one-sided difference mean test). Data represent means $\pm \operatorname{SE}(n=60)$.

Table 2. Pair-wise a posteriori comparisons of the environmental characteristics (from Table 1) after a two-way, semi-parametric, MANOVA (PERMANOVA)

(A) Randomly located points and points containing an individual plant

\begin{tabular}{llll}
\hline & Age class & $t$ & $P($ perm $)$ \\
\hline Random located points & Seedlings vs. young saplings & 0.8374 & 0.6299 \\
& Seedlings vs. old saplings & 1.1918 & 0.2105 \\
& Young saplings vs. old saplings & 1.1624 & 0.2434 \\
& & & 0.0007 \\
Individual plants & Seedlings vs. young saplings & 2.1229 & 0.0001 \\
& Seedlings vs. old saplings & 2.8987 & 0.0055 \\
\hline
\end{tabular}

(B) Age classes (seedlings $=1$ year old; young saplings $=$ from 2 to 5 years old; and old saplings $=$ from 6 to 10 years old)

\begin{tabular}{llll}
\hline & Points & $t$ & $P$ (perm) \\
\hline Seedlings & 1,2 & 1.308 & 0.1283 \\
Young saplings & 1,2 & 1.474 & 0.0560 \\
Old saplings & 1,2 & 1.688 & 0.0117 \\
\hline
\end{tabular}

Points as follows: $1=$ with an $A$. opalus individual; and $2=$ randomly located (without an $A$. opalus individual).

$F=1.68, P=0.0711)$. This interaction was explained by the fact that the environmental characteristics of the random points did not differ among age classes, but those of the points containing seedlings/saplings did (Table 2A). Differences in the environmental characteristics of points with and without plants increased with age, from nonsignificant in seedlings to highly significant in old saplings (Table 2B).

The first two PCO axes explained over $50 \%$ of the variation observed in the data, and clearly separated the points with and without $A$. opalus individuals, as well as those occupied by seedlings from those occupied by saplings (Fig. 1). Most environmental variables measured were correlated with the first two PCO axes (Table 3). As large sample sizes (this study: $n=360$ ) are more likely to produce statistically significant results (Chow, 1988), we emphasize only those variables with correlation coefficients $(\rho) \geqslant 0.6$. The first axis of this ordination was positively correlated with tree cover, and negatively with shrub cover (Table 3 ). Second axis was positively correlated with the depth of litter layer. These results suggest a gradient along axis 1, where the 
environment of seedlings is characterized by higher tree cover and lower shrub cover than that of young and old saplings, in this order. Axis 2 determined a gradient from decreased depth of litter layer in seedlings as compared to that found in young and old saplings (Fig. 1).

Herbivory damage in old saplings differed among microsites $\left(F_{3,56}=3.97, \quad P<0.05\right)$. Saplings growing

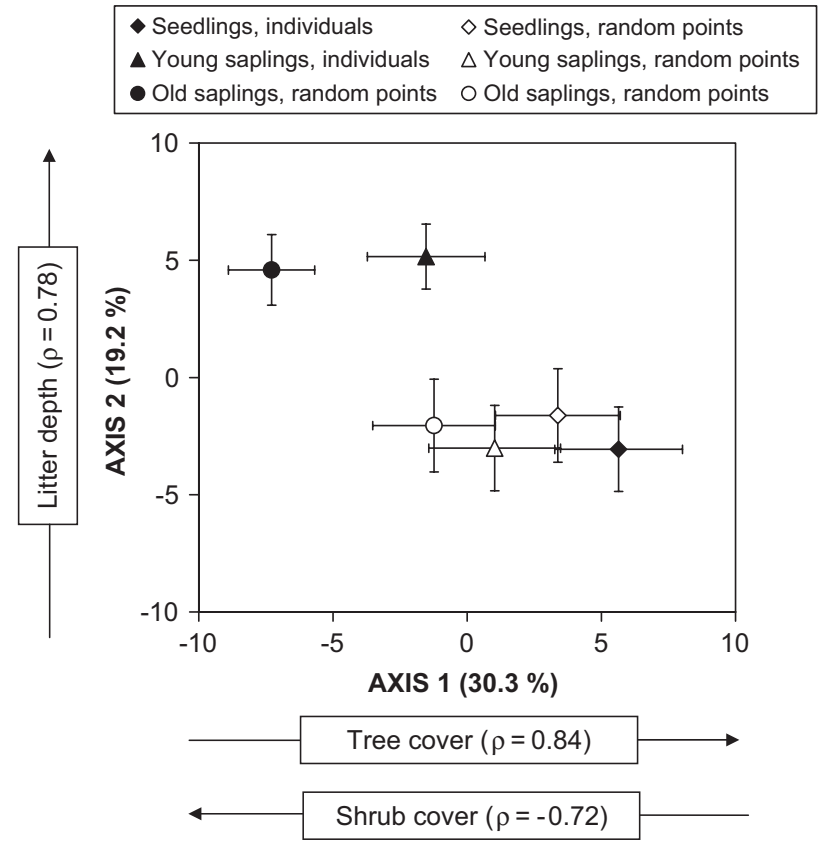

Fig. 1. Principal-coordinate analysis of the environmental variables characterizing the sampling points with and without Acer opalus ssp. granatense. Age classes as follows: seedlings $=1$ year old; young saplings $=$ from 2 to 5 years old; and old saplings $=$ from 6 to 10 years old. Data represent means $\pm \operatorname{SE}(n=60)$. among non-palatable shrubs sustained less damage than those growing in open areas, palatable shrubs or under trees (Fig. 2).

\section{Discussion}

Three questions regarding the regeneration niche of the endangered tree A. opalus ssp. granatense were considered: whether ontogenetic shifts occur, whether these changes showed expansion or contraction, and what variables drive these shifts. Our results suggest that niche shifts among the different demographic stages studied are occurring (Table 2A). In addition, we found that differences in microsites between individual plants

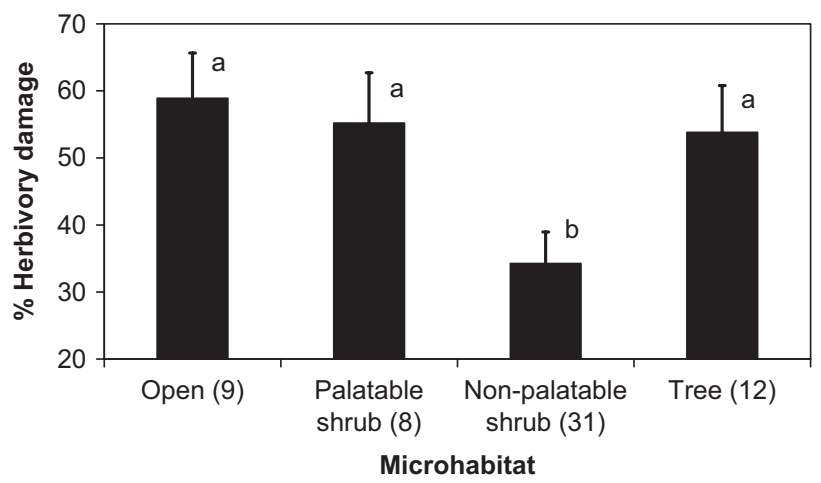

Fig. 2. Herbivory damage in Acer opalus ssp. granatense old saplings (from 6 to 10 years-old), estimated as the percentage of consumed twigs, in different microhabitats according to predominate cover. Palatability classification was based on Baraza et al. (2006). Columns and error bars show means \pm SE. Sample size in each microhabitat $(n=60$ as whole) are indicated. Different letters show significant differences among microhabitats at $P<0.05$ (HSD Tukey test for unequal $n$ ).

Table 3. Correlation matrix between the environmental variables evaluated and the two first axes from a principal coordinate analysis

\begin{tabular}{lrrrrr}
\hline Variables & \multicolumn{2}{c}{ Axis 1} & & \multicolumn{2}{c}{ Axis 2} \\
\cline { 2 - 3 } & Spearman's $\rho$ & $P$-values & & Spearman's $\rho$ & $P$-values \\
\hline Average compaction & 0.035 & 0.502 & -0.238 & $<0.001$ \\
Depth of maximum compaction & -0.147 & $<0.01$ & 0.290 & $<0.001$ \\
Global site factor & -0.553 & $<0.001$ & -0.548 & $<0.001$ \\
Herbaceous cover & -0.097 & 0.065 & -0.124 & 0.018 \\
Litter depth & -0.074 & 0.161 & $\mathbf{0 . 7 8 0}$ & $<\mathbf{0 . 0 0 1}$ \\
Moss cover & -0.263 & $<0.001$ & 0.397 & $<0.001$ \\
Distance to nearest adult A. opalus & -0.338 & $<0.001$ & -0.173 & $<0.001$ \\
Shrub cover & $-\mathbf{0 . 7 1 5}$ & $<\mathbf{0 . 0 0 1}$ & 0.441 & $<0.001$ \\
Stone cover & -0.133 & 0.011 & -0.356 & $<0.001$ \\
Tree cover & $\mathbf{0 . 8 4 1}$ & $<\mathbf{0 . 0 0 1}$ & 0.105 & 0.045 \\
Number of individual of woody species & -0.500 & $<0.001$ & 0.259 & $<0.001$ \\
\hline
\end{tabular}

$P$-values $\geqslant 0.0022$ are not significant according to Bonferroni multiple comparison test. The highest correlation coefficients $(\rho \pm \geqslant 0.6)$ and their $P$-values are shown in bold type. 
and randomly located points became larger with sapling age (Table 2B). The environment surrounding seedlings did not differ from that of random points, which is in agreement with previous results indicating that $A$. opalus seeds arrive and germinate in a wide array of microsites (Gómez-Aparicio, Gómez, et al., 2005). However, microsites of $A$. opalus saplings were characterized by higher shrub and lower tree cover than those of randomly located points, especially in the oldest age class. Furthermore, old saplings underwent differential damage by herbivores, depending on microhabitat (Fig. 2). All of these findings suggest that a contraction of the regeneration niche is taking place in A. opalus (i.e., niche requirements become more restrictive with age). Tree cover, shrub cover and litter depth, together with herbivory, were the principal factors governing these changes (Table 3 and Fig. 2).

Concerning niche breadth, since niche requirements become more restrictive with sapling age (Table 2B), the regeneration niche of $A$. opalus shifts during ontogeny undergoes a contraction. Wind-dispersed seeds of $A$. opalus reach and germinate in all available microhabitats, but saplings establish and grow only in a subset of those available. These results correspond to ontogenetic shifts in tolerance to extrinsic factors and/or resource use, and agree with previous studies showing that conditions for successful establishment are more stringent than those for successful germination (Turnbull, Crawley, \& Rees, 2000). A narrowing of niche through ontogeny can be considered a critical component of spatiotemporal dynamics (Miriti, 2006) acting as an ecological restriction on the observed abundance patterns of $A$. opalus populations.

Microsites occupied by $A$. opalus saplings were characterized by low tree and high shrub cover, especially in the oldest age class. Therefore, the regeneration niche of $A$. opalus arises under the canopy of shrubs, far away from adult trees, a pattern found for most woody species in Mediterranean environments (Castro, Zamora, Hódar, \& Gómez, 2004; GómezAparicio, Gómez, et al., 2004; Rey \& Alcántara, 2000). Negative effects of adult trees on the establishment of woody plants have been previously reported (e.g., Li \& Ma, 2003; Maestre, Cortina, Bautista, \& Bellot, 2003), suggesting an increase in asymmetrical competitive interactions between saplings (the weaker competitors) and the adult trees (the stronger competitors) with age for resources (Buckley, Sharik, \& Isebrands, 1998; Lorimer, 1984). However, these effects are speciesspecific (Reinhart, Maestre, \& Callaway, 2006) and depend on environmental conditions (Callaway, 1998; Maestre, Cortina, \& Bautista, 2004). The high shrub cover found in areas occupied by older individuals (Table 1), and the strong (and negative) correlation between this variable and the first PCO axis (Table 3), suggest that shrub cover is a crucial factor to ensure the establishment of $A$. opalus saplings (Gómez-Aparicio, Zamora, et al., 2005). It is noteworthy that none of the
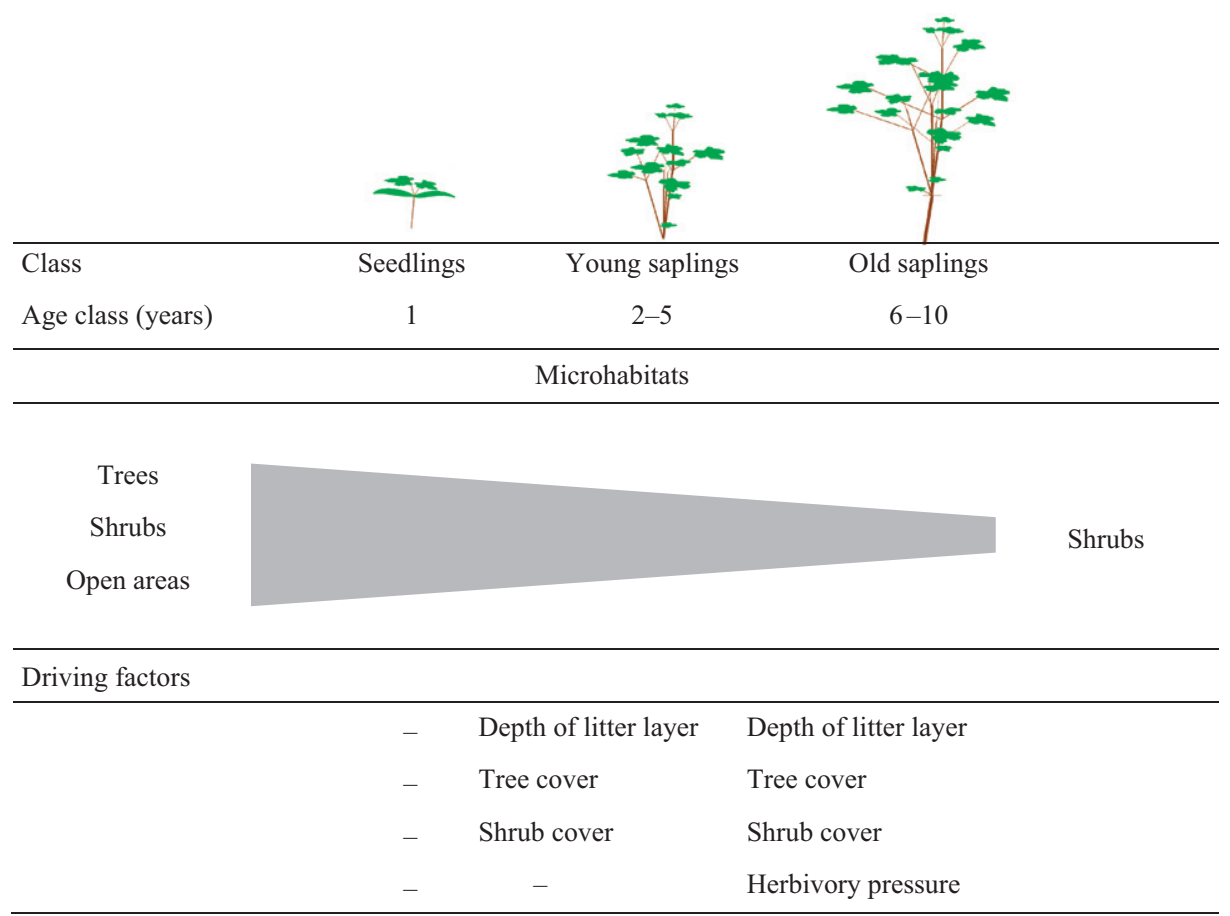

Fig. 3. Conceptual scheme showing the principal factors driving the regeneration niche of Acer opalus ssp. granatense through ontogeny. Grey area indicates $A$. opalus niche contraction and positive or negative driving factors influencing the successful establishment of $A$. opalus are shown. 
individual abiotic factors was better than shrub cover for predicting $A$. opalus recruitment patterns. Furthermore, a protective effect of non-palatable, spiny shrubs against herbivory was discerned (Fig. 2, see also Baraza et al., 2006). These results were presumably because shrubs provide an array of environmental properties crucial for the successful establishment of $A$. opalus saplings under the stressful Mediterranean conditions. In this context, we propose a conceptual scheme that shows the principal factors driving the ontogenetic niche shifts of A. opalus (Fig. 3). After seed dispersal, there are no critical conditions for seed germination or early seedling establishment (Gómez-Aparicio, Gómez, et al., 2005). However, in later stages, factors emerge to impose more restrictive conditions for establishment: (i) deeper litter could favour soil-moisture retention, (ii) shrub cover favours plant performance by: (1) alleviating stressful Mediterranean summer drought conditions for seedlings and young saplings and (2) if shrubs are non-palatable and spiny, protecting old saplings from herbivores; (iii) lastly, the tree cover could block light required in the oldest stage. These results indicate an ontogenetic shift in plant-plant interactions. Saplings of A. opalus experienced a positive interaction from shrubs (facilitation), but a negative interaction from adult trees (asymmetrical competition).

Ontogenetic niche shifts constitute an ecological concept largely unexplored when restoring degraded populations and ecosystems (Young, Petersen, \& Clary, 2005). We provide new empirical evidence that can be applied to optimize management and restoration programmes involving woody species. A. opalus populations in Mediterranean mountains show remnant dynamics (sensu Eriksson, 1996), and small populations are maintained by the longevity of a few old individuals (Gómez-Aparicio, Zamora, et al., 2005). Effective restoration activities may broaden the regeneration niche through assisted establishment, since it is strongly needed to ensure viable populations of this species in many places (Gómez-Aparicio, Gómez, et al., 2004). This can be achieved by planting seedlings or sowing seeds of this tree in areas microhabitats with a high nonpalatable shrub cover and a deep litter layer, in addition to avoiding both bare ground soil and dense tree cover. These results reinforce the common pattern of nurse effects of shrubs observed in Mediterranean environments (Castro, Zamora, Hódar Gómez, \& GómezAparicio, 2004; Gómez-Aparicio, Gómez, et al., 2004).

In summary, the spatial pattern of $A$. opalus establishment shifts ontogenetically with the presence of shrubs, adult trees, depth of the litter layer and herbivory as the main factors influencing this change. These niche characteristics are a subset of the overall suitable microsites for seed germination and seedling establishment (Fig. 3). In our study, ontogenetic shifts represent changes both in tolerance to extrinsic factors and in the nature and strength of plant-plant interactions. As a result, $A$. opalus population fate is strongly dependent on availability of neighbouring shrubs.

\section{Acknowledgements}

We thank to Luis Matías Resina for their help during the field and office work. David Nesbitt looked over the English version of the manuscript. This study was supported by the Grant FPI-MEC to JLQ (BES-20031716), and by the coordinated Spanish CICYT projects HETEROMED (REN2002-04041) and DINAMED (CGL2005-05830). LGA was supported by a postdoctoral fellowship from the University of Granada and by a Fullbright postdoctoral fellowship (FU2004-1288) from the Spanish Ministerio de Educación y Ciencia (MEC). FTM was supported by Fullbright (FU20030398) and Ramón y Cajal research fellowships from MEC. This research is part of the REDBOME (http:// www.ugr.es/ redbome/) and GLOBIMED (http:// www.globimed.net) networks on forest ecology.

\section{References}

Amundsen, P. A., Bohn, T., Popova, O. A., Staldvik, F. J., Reshetnikov, Y. S., Kashulin, N. A., et al. (2003). Ontogenetic niche shifts and resource partitioning in a subarctic piscivore fish guild. Hydrobiology, 497, 109-119.

Anderson, M. J. (2001). A new method for non-parametric multivariate analysis of variance. Austral Ecology, 26, 32-46.

Anderson, M. J. (2004). CAP: A FORTRAN computer program for canonical analysis of principal coordinates, Department of Statistics, University of Auckland, New Zealand.

Anderson, M. J. (2005). PERMANOVA: A FORTRAN computer program for permutational multivariate analysis of variance, Department of Statistics, University of Auckland, New Zealand.

Anderson, M. J., \& Ter Braak, C. J. F. (2003). Permutation tests for multi-factorial analysis of variance. Journal of Statistical Computation and Simulation, 73, 85-113.

Anderson, M. J., \& Willis, T. J. (2003). Canonical analysis of principal coordinates: A useful method of constrained ordination for ecology. Ecology, 84, 511-525.

Baraza, E., Zamora, R., \& Hódar, J. A. (2006). Conditional outcomes in plant-herbivore interactions: Neighbours matter. Oikos, 113, 148-156.

Blanca, G., Cabezudo, B., Hernández-Bermejo, J. E., Herrera, C. M., Muñoz, J., \& Valdés, B. (2000). Libro Rojo de Flora Amenazada de Andalucía. Consejería de Medio Ambiente, Junta de Andalucía, Sevilla.

Boerner, R. E. J., \& Brinkman, J. A. (1996). Ten years of tree seedlings establishment and mortality in an Ohio deciduous forest complex. Bulletin of the Torrey Botanical Club, 123, 309-317. 
Buckley, D. S., Sharik, T. L., \& Isebrands, J. G. (1998). Regeneration of northern red oak: Positive and negative effects of competitor removal. Ecology, 79, 65-78.

Callaway, R. M. (1995). Positive interactions among plants. Botanical Review, 61, 306-349.

Callaway, R. M. (1998). Competition and facilitation on elevation gradients in subalpine forests of the northern Rocky Mountains, USA. Oikos, 82, 561-573.

Castro, J., Zamora, R., \& Hódar, J. A. (2006). Restoring a Quercus pyrenaica forest using pioneer shrubs as nurse plants. Applied of Vegetation Science, 9, 137-142.

Castro, J., Zamora, R., Hódar, J. A., \& Gómez, J. M. (2004). Seedling establishment of a boreal tree species (Pinus sylvestris var. nevadensis) at its southernmost distribution limits: Consequence of being in a marginal Mediterranean habitat. Journal of Ecology, 92, 266-277.

Castro, J., Zamora, R., Hódar, J. A., Gómez, J. M., \& GómezAparicio, L. (2004). Benefits of using shrubs as nurse plants for reforestaion in Mediterranean mountais: A 4-years study. Restoration Ecology, 12, 352-358.

Cavender-Bares, J., \& Bazzaz, F. A. (2000). Changes in drought response strategies with ontogeny in Quercus rubra: Implications for scaling from seedlings to mature trees. Oecologia, 124, 8-18.

Chase, J. M., \& Leibold, M. A. (2003). Ecological niches: Linking classical and contemporary approaches. Chicago \& London: The University of Chicago Press.

Chow, S. L. (1988). Significance test or effect size? Psychological Bulletin, 103, 105-110.

Costa, M., Morla, C., \& Sainz, H. (1998). Los Bosques Ibéricos. Barcelona: Editorial Planeta.

Delgado, R., Delgado, G., Párraga, J., Gámiz, E., Sánchez, M., \& Tenorio, M. A. (1989). Mapa de suelos, hoja 1027 (Güejar-Sierra). Instituto para la Conservación de la Naturaleza, Madrid.

Eriksson, O. (1996). Regional dynamics of plants: A review of evidence for remnant, source-sink and metapopulations. Oikos, 77, 248-258.

Eriksson, O. (2002). Ontogenetic niche shifts and their implications for recruitment in three clonal Vaccinium shrub: Vaccinium myrtillus, Vaccinium vitis-idaea, and Vaccinium oxycoccos. Canadian Journal of Botany, 80, 635-641.

Espelta, J. M., Riba, M., \& Retana, J. (1995). Patterns of seedling recruitment in west-mediterranean Quercus ilex forests influenced by canopy development. Journal of Vegetation Science, 6, 465-472.

Franco, A. C., \& Nobel, P. S. (1989). Effect of nurse plants on the microhabitat and growth of cacti. Journal of Ecology, 77, 870-886.

García, D., Zamora, R., Hódar, J. A., Gómez, J. M., \& Castro, J. (2000). Yew (Taxus baccata L.) regeneration is facilitated by fleshy-fruited shrubs in Mediterranean environments. Biological Conservation, 95, 31-38.

Gómez-Aparicio, L., Gómez, J. M., \& Zamora, R. (2005). Microhabitats shift rank in suitability for seedling establishment depending on habitat type and climate. Journal of Ecology, 93, 1194-1202.

Gómez-Aparicio, L., Valladares, F., Zamora, R., \& Quero, J. L. (2005). Response of tree seedlings to the abiotic heterogeneity generated by nurse shrubs: An experimental approach at different scales. Ecography, 28, 757-768.

Gómez-Aparicio, L., Zamora, R., \& Gómez, J. M. (2005). The regeneration status of the endarged Acer opalus ssp. granatense throughout its geographical distribution in the Iberian Peninsula. Biological Conservation, 121, 195-206.

Gómez-Aparicio, L., Zamora, R., Castro, J., \& Hódar. Facilitation of tree saplings by nurse plants: Microhabitat amelioration or protection against herbivores? Journal of Vegetation Science, in press.

Gómez-Aparicio, L., Zamora, R., Gómez, J. M., Hódar, J. A., Castro, J., \& Baraza, E. (2004). Applying plant facilitation to forest restoration: A meta-analysis of the use of shrubs as nurse plants. Ecological Applications, 14, 1128-1138.

Grubb, P. J. (1977). The maintenance of species-richness in plant communities: The importance of the regeneration niche. Biological Review, 52, 107-145.

Holmgren, M., Scheffer, M. A., \& Huston, A. (1997). The interplay of facilitation and competition in plant communities. Ecology, 78, 1966-1975.

Holzapfel, C., \& Mahall, B. E. (1999). Bidirectional facilitation and interference between shrubs and annuals in the Mojave Desert. Ecology, 80, 1747-1761.

Kitajima, K., \& Fenner, M. (2000). Ecology of seedling regeneration. In M. Fenner (Ed.), Seeds: The ecology of regeneration in plant communities (2nd ed., pp. 331-359). Wallingford: CAB International.

Li, Q., \& Ma, K. (2003). Factors affecting establishment of Quercus liaotungensis Koidz. under mature mixed oak forest overstory and in shrubland. Forest Ecology and Management, 176, 133-146.

Lorimer, C. G. (1984). Development of the red maple understory in northeastern oak forests. Forest Science, 30, $3-22$.

Maestre, F. T., Cortina, J., \& Bautista, S. (2004). Mechanisms underlying the interaction between Pinus halepensis and the native late-successional shrub Pistacia lentiscus in a semiarid plantation. Ecography, 27, 776-786.

Maestre, F. T., Cortina, J., Bautista, S., \& Bellot, J. (2003). Does Pinus halepensis facilitate the establishment of shrubs in Mediterranean semi-arid afforestations? Forest Ecology and Management, 176, 147-160.

McArdle, B. H., \& Anderson, M. J. (2001). Fitting multivariate models to community data: A comment on distancebased redundancy analysis. Ecology, 82, 290-297.

Miriti, M. (2006). Ontogenetic shift from facilitation to competition in a desert shrub. Journal of Ecology, 94, 973-979.

Parrish, J. A. D., \& Bazzaz, F. A. (1985). Ontogenetic niche shifts in old-fields annuals. Ecology, 66, 1296-1302.

Post, D. M. (2003). Individual variation in the timing of ontogenetic niche shifts in largemouth bass. Ecology, 84, 1298-1310.

Quinn, G. P., \& Keough, M. J. (2002). Experimental design and data analysis for biologists. Cambridge: Cambridge University Press.

Reinhart, K. O., Maestre, F. T., \& Callaway, R. M. (2006). Facilitation and inhibition of seedlings of an invasive tree (Acer platanoides) by different tree species in a mountain ecosystem. Biological Invasions, 8, 231-240. 
Rey, P. J., \& Alcántara, J. M. (2000). Recruitment dynamics of a fleshy-fruited plant Olea europaea: Connecting patterns of seed dispersal to seedling establishment. Journal of Ecology, $88,622-633$.

Rich, P. M. (1990). Characterizing plant canopies with hemispherical photographs. Remote Sensing Review, 5, 13-29.

Schupp, E. W., \& Fuentes, M. (1995). Spatial patterns of seed dispersal and the unification of plant-population ecology. Ecoscience, 2, 267-275.

Silvertown, J. (2004). Plant coexistence and the niche. Trends in Ecology \& Evolution, 19, 605-611.

Taylor, K. M., \& Aarssen, L. W. (1989). Neighbour effect in mast year seedling of Acer saccharum. American Journal of Botany, 76, 546-554.

Turkington, R., \& Harper, J. L. (1979). The growth, distribution and neighbour relationships of Trifolium repens in a permanent pasture. I. Ordination, pattern and contact. Journal of Ecology, 67, 201-218.

Turnbull, L. A., Crawley, M. J., \& Rees, M. (2000). Are plant populations seed-limited? A review of seed sowing experiments. Oikos, 88, 225-238.

Young, T. P., Petersen, D. A., \& Clary, J. J. (2005). The ecology of restoration: Historical links, emerging issues and unexplored realms. Ecology Letters, 8, 662-673.

Zamora, R., Gómez, J. M., Hódar, J. A., Castro, J., \& García, D. (2001). Effect of browsing by ungulates on sapling growth of Scots pine in a Mediterranean environment: Consequences for forest regeneration. Forest Ecology and Management, 144, 33-42.

Zoladeski, C. A., \& Maycock, P. F. (1990). Dynamics of the boreal forest in Northwestern Ontario. American Midland Naturalist, 124, 289-300. 